\title{
Efektivitas Pembelajaran Daring di Masa Pandemi Covid-19: Persepsi Mahasiswa Pendidikan Biologi
}

\author{
Agus Muliadi ${ }^{1}$, Baiq Mirawati ${ }^{2}$, Husnul Jannah ${ }^{3}$ \\ ${ }^{1,2,3}$ Pendidikan Biologi, FSTT, Universitas Pendidikan Mandalika, Indonesia \\ E-mail: agusmuliadi@ikipmataram.ac.id
}

\begin{abstract}
Abstrak: Tujuan penelitian ini adalah untuk mengetahui persepsi mahasiswa pendidikan biologi terhadap efektivitas pembelajaran daring pada masa pandemi Covid-19. Penelitian ini merupakan penelitian ex post facto dengan pendekatan deskriptif eksploratif. Sampel penelitian ini adalah mahasiswa Program Studi Pendidikan Biologi Universitas Pendidikan Mandalika sebanyak 38 orang yang ditentukan dengan teknik convenience sampling. Penelitian ini dilaksanakan pada Semester Genap Tahun Akademik 2019/2020 atau awal masa pandemi covid-19 di Indonesia. Instrumen yang digunakan adalah angket tertutup tentang persepsi mahasiswa pendidikan biologi terhadap pembelajaran daring dengan jawaban berdegradasi sesuai skala likert dan telah divalidasi ahli. Teknik analisis data yang digunakan yaitu statistik deskriptif. Hasil penelitian ini menunjukkan bahwa (1) persepsi mahasiswa pendidikan biologi adalah $>70 \%$ memberikan respon negatif pada setiap jawaban tentang efektivitas pembelajaran daring, (2) analisis deskriptif data persepsi mahasiswa pendidikan biologi terhadap pembelajaran daring menghasilkan rata-rata sebesar 2,28 atau kategori Cukup Baik. Oleh sebab itu, dapat disimpulkan bahwa pembelajaran daring di Program Studi Pendidikan Biologi pada Semester Genap Tahun Akademik 2019/2020 atau awal pandemi covid-19 berlangsung kurang efektif.
\end{abstract}

Kata kunci: pembelajaran daring, pandemi covid-19, persepsi mahasiswa

\section{PENDAHULUAN}

Pendidikan mempunyai arti usaha sadar untuk menyiapkan peserta didik melalui kegiatan bimbingan, pengajaran, dan latihan demi peranannya dimasa mendatang. Kegiatan pembelajaran merupakan salah satu komponen utama dalam pendidikan yang pelaksanaanya harus dipastikan dapat terselenggara secara baik dan berkesinambungan (Maulah, Nurul \& Ummah, 2020). Pemerintah Indonesia harus mampu memastikan kegiatan pembelajaran pada masa pandemi covid-19 ini dapat terus berlangsung melalui berbagai regulasi dan metode yang terbaik dengan mematuhi protokol kesehatan demi menjaga kesehatan dan keselamatan jiwa pendidik, tenaga kependidikan, dan peserta didik.

Pandemi wabah corona virus disease 2019 (covid-19) telah berlangsung lebih dari satu tahun dan melanda 215 negara di dunia termasuk Indonesia. Seluruh aspek kehidupan di dunia terdampak secara serius oleh pandemi covid-19. Dampak covid-19 di Indonesia telah merambah sampai dunia pendidikan termasuk Perguruan Tinggi. Untuk melawan covid-19, pemerintah pusat hingga daerah telah mengeluarkan berbagai bentuk kebijakan untuk dapat menghentikan penyebarannya seperti larangan berkerumun, pembatasan sosial (social distancing), menjaga jarak fisik (physical distancing), memakai masker dan selalu cuci tangan (Gultom \& Sitanggang, 2020; Sadikin \& Hamidah, 2020).

Wabah covid-19 telah menginfeksi lebih dari 1 juta orang di Indonesia. Seiring terus bertambahnya angka pasien positif covid-19 di Indonesia, pemerintah melalui Kemendikbud telah mengeluarkan kebijakan tentang penyelenggaraan pembelajaran daring (online) melalui terbitnya Surat Edaran Nomor 3 Tahun 2020 tentang Pencegahan covid-19 pada satuan pendidikan. Program pembelajaran daring atau belajar dari rumah ini telah diterapkan dari berbagai tingkatan pendidikan di Indonesia, tak terkecuali di tingkat perguruan tinggi. Hal ini sesuai dengan pendapat Firman \& Rahayu (2020) bahwa perguruan tinggi dituntut untuk dapat menyelenggarakan pembelajaran secara daring atau online.

Menindaklanjuti edaran kemendikbud tersebut, semua perguruan tinggi merespon dan menyelengarakan pembelajaran daring (online), termasuk Universitas Pendidikan Mandalika dengan meniadakan perkuliahan konvesional dan menggantinya dengan 
pembelajaran daring. Pembelajaran daring merupakan kebijakan nasional sebagai langkah strategis dalam upaya pencegahan penyebaran virus covid-19. Oleh sebab itu, peroses pembelajaran daring (online) di Program Studi Pendidikan Biologi Fakultas Sains, Teknik, dan Terapan (FSTT) Universitas Pendidikan Mandalika dilaksanakan dengan memanfaatkan teknologi dan media internet secara synchronous atau asynchronous. Perkembangan teknologi informasi komunikasi di era 4.0 yang pesat memudahkan dalam keberlangsungan perkuliahan daring. Media sosial sebagai media daring yang memudahkan para penggunanya berkomunikasi antarmuka, berpartisipasi, dan berbagi. Sedangkan bagi dosen, adanya pembelajaran daring ini yang mengubah total pola pembelajaran dari metode tradisional (tatap muka) menjadi pembelajaran daring (online), secara tidak langsung menguji kompetensi, profesionalisme, dan keterampilan dosen dalam mengajar (Maulah, Nurul \& Ummah, 2020; Pangondian, Santosa, \& Nugroho, 2019).

Pembelajaran daring merupakan pembelajaran yang menggunakan jaringan internet dengan aksesibilitas, konektivitas, fleksibilitas, dan kemampuan untuk memunculkan berbagai jenis interaksi pembelajaran (Sadikin \& Hamidah, 2020). Penelitian yang dilakukan oleh Zhang et al., (2004) (dalam Sadikin \& Hamidah, 2020) menunjukkan bahwa penggunaan internet dan teknologi multimedia mampu merombak cara penyampaian pengetahuan dan dapat menjadi alternatif pembelajaran yang dilaksanakan dalam kelas tradisional. Kuntoro (2017) menjelaskan bahwa pembelajaran yang mampu mempertemukan mahasiswa dan dosen untuk melaksanakan interaksi pembelajaran dengan bantuan internet.

Pembelajaran daring diharapkan menjadi momentum untuk mengembangkan model pembelajaran inovatif berbasis teknologi dengan harapan efektif untuk menggantikan pembelajaran dengan sistem tatap muka lansung di kelas (teacher-directed learning) (Saifuddin, 2017). Pada pembelajaran konvensional, selama ini mahasiswa cenderung hanya bersikap reaktif terhadap kondisi lingkungannya, tetapi tidak berperan aktif untuk lingkungannya (Yuniarti, 2010). Pembelajaran daring dapat meningkatkan peran mahasiswa dalam proses pembelajaran. Layanan pembelajaran daring telah tersedia baik yang dikelola mandiri oleh institusi dengan Learning Management System (LMS) maupun pihak ketiga seperti media sosial. Menurut Zhafira, et al. (2020) dengan menggunakan pembelajaran daring dapat meningkatkan interaktivitas dan efisiensi belajar karena memberikan mahasiswa potensi yang lebih tinggi untuk berkomunikasi lebih banyak dengan dosen, rekan, dan mengakses lebih banyak materi pembelajaran.

Penerapan pembelajaran daring pada masa pandemi di Fakultas Sains, Teknik, dan Terapan (FSTT) Universitas Pendidikan Mandalika pada awal pandemi covid-19 di Semester Genap Tahun Akademik 2019/2020 sangat mendadak karena jadwal perkuliahan dengan metode konvensional (tatap muka) sudah mulai berlangsung. Hal ini mengakibatkan persiapan media pembelajaran daring seperti Learning Management System (LMS) belum maksimal, sehingga dosen dihimbau untuk menyelenggarakan pembelajaran daring dengan berbagai media yang ada, minimal menggunakan media WhatsApp. Oleh sebab itu, diperlukan adanya pemetaan persepsi mahasiswa terhadap pelaksanaan pembelajaran daring pada Pendidikan Biologi FSTT Universitas Pendidikan Mandalika di Semester Genap Tahun Akademik 2019/2020.

\section{METODE PENELITIAN}

Penelitian ini merupakan penelitian ex post facto dengan pendekatan deskriptif eksploratif. Penelitian ex post facto adalah penelitian untuk mengkaji hubungan sebab akibat yang tidak dimanipulasi atau tidak diberikan perlakukan oleh peneliti, namun peneliti hanya merekam data dari kegiatan yang sudah terjadi. Kajian deskriptif eskloratif digunakan untuk mendeskripsikan persepsi mahasiswa pendidikan biologi terhadap efektivitas perkuliahan daring (Muliadi, 2020; Sugiyono, 2017; Arikunto, 2016; Singarimbun 
\& Sofyan, 2009). Responden penelitian ini adalah mahasiswa pendidikan biologi Fakultas Sains, Teknik, dan Terapan (FSTT) Universitas Pendidikan Mandalika sebanyak 38 orang yang ditetapkan dengan teknik convenience sampling karena mempertimbangkan aksesibilitas responden dalam mengisi angket secara online pada masa pandemi covid-19 (Fink, 2011).

Penelitian ini dilaksanakan pada semester genap Tahun Akademik 2019/2020 atau pada awal pandemi covid-19 di Indonesia. Intrumen penelitian yang digunakan adalah angket tertutup dengan jawaban sikap yang berdegradasi sesuai skala likert (Muliadi, 2020). Instrumen disusun mengacu pada indikator indikator persepsi yang dikembangkan oleh Adijaya \& Santosa (2018) yaitu interaksi pembelajaran, manajemen pembelajaran, evaluasi pembelajaran, lingkungan belajar. Angket penelitian ini terdiri atas 14 pernyataan dan telah divalidasi oleh para pakar (expert) dan dinyatakan valid (Muliadi, et al., 2019; Muliadi, 2020; Muliadi \& Mirawati, 2020; Muliadi, Asri \& Lestarini, 2020).

Analisis data penelitian yang digunakan adalah statistik deskriptif. Statistik deskriptif digunakan untuk mendeskripsikan persepsi mahasiswa pendidikan biologi terhadap pembelajaran daring pada masa pandemi covid-19. Rata-rata data persepsi dikonversi dalam bentuk kategori dengan mengacu pada kategori penilaian sikap yang dikembangkan Kementerian Pendidikan dan Kebudayaan tahun 2013 (Muliadi, 2020) yaitu:

Tabel 1. Interpretasi skor persepsi mahasiswa

\begin{tabular}{cc}
\hline Rata-rata skor & Interpretasi \\
\hline $3,51-4,00$ & Sangat Baik \\
$2,51-3,50$ & Baik \\
$1,51-2,50$ & Cukup Baik \\
$1,00-1,50$ & Kurang Baik \\
\hline
\end{tabular}

\section{HASIL DAN PEMBAHASAN}

Hasil respon mahasiswa diperoleh informasi bahwa media pembelajaran daring yang digunakan dosen pendidikan biologi pada semester genap Tahun Akademik 2019/2020 yaitu WhatsApp, Google Classroom, Zoom Meeting, Cisco Webex Meet, dan e-mail.
Analisis data menjelaskan bahwa $47 \%$ dosen menggunakan WhatsApp, $21 \%$ menggunakan WhatsApp dan Google Classroom, 13\% menggunakan media Google Classroom, dan 19\% menggunakan WhatsApp dan Zoom Meeting. Deskripsi data ini menggambarkan bahwa pembelajaran daring diselenggarkan dosen umumnya menggunakan WhatsApp. Deskripsi data tersebut dipertegas dengan gambar 1 berikut ini.

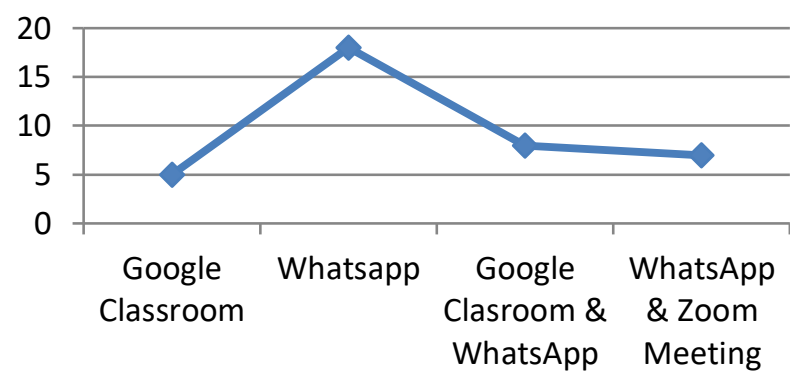

Gambar 1. Penggunaan media pembelajaran daring

Deskripsi data hasil pengukuran persepsi mahasiswa terhadap pembelajaran daring pendidikan biologi pada semester genap Tahun Akademik 2019/2020 di awal masa pandemi covid-19, dijelaskan berdasarkan respon mahasiswa terhadap 14 butir pertanyaan. Setiap butir pertanyaan memiliki pilihan jawaban dengan skala likert yaitu Sangat Setuju (SS), Setuju (S), Kurang Setuju (KS), dan Tidak Setuju (TS). Hasil jawaban responden disajikan pada Tabel 2 berikut ini.

Tabel 2. Persepsi mahasiswa tentang pembelajaran daring

\begin{tabular}{ccccc}
\hline Pertanyaan & SS & S & KS & TS \\
\hline 1 & $0 \%$ & $13 \%$ & $55 \%$ & $32 \%$ \\
\hline 2 & $27 \%$ & $55 \%$ & $13 \%$ & $5 \%$ \\
\hline 3 & $11 \%$ & $66 \%$ & $18 \%$ & $5 \%$ \\
\hline 4 & $0 \%$ & $16 \%$ & $58 \%$ & $26 \%$ \\
\hline 5 & $34 \%$ & $47 \%$ & $16 \%$ & $3 \%$ \\
\hline 6 & $0 \%$ & $19 \%$ & $63 \%$ & $18 \%$ \\
\hline 7 & $24 \%$ & $58 \%$ & $18 \%$ & $0 \%$ \\
\hline 8 & $3 \%$ & $24 \%$ & $52 \%$ & $21 \%$ \\
\hline 9 & $13 \%$ & $58 \%$ & $24 \%$ & $5 \%$ \\
\hline 10 & $29 \%$ & $58 \%$ & $13 \%$ & $0 \%$ \\
\hline 11 & $0 \%$ & $24 \%$ & $66 \%$ & $10 \%$ \\
\hline 12 & $5 \%$ & $50 \%$ & $34 \%$ & $11 \%$ \\
\hline 13 & $5 \%$ & $42 \%$ & $48 \%$ & $5 \%$ \\
\hline 14 & $8 \%$ & $55 \%$ & $37 \%$ & $0 \%$ \\
\hline
\end{tabular}


Elaborasi data persepsi mahasiswa terhadap pembelajaran daring yang disajikan pada Tabel 2 adalah sebagai berikut:

1. Pembelajaran daring memudahkan saya berinteraksi dengan dosen. Pada pertanyaan ini, mahasiswa sebanyak $55 \%$ menjawab Kurang Setuju, 32\% Tidak Setuju, 13\% Setuju, 0\% Sangat Setuju. Respon mahasiswa ini menjelaskan bahwa $87 \%$ mahasiswa memberikan respon negatif dan menjadi peringatan (warning) serius bagi dosen dalam melaksanakan pembelajaran daring, karena interaksi pembelajaran antara dosen dan mahasiswa sangat penting untuk membangun komunikasi dua arah dalam suatu proses pembelajaran. Hal ini dapat disebabkan karena persiapa dosen dan mahasiswa yang kurang dan sangat mendesak untuk menyelenggarakan pembelajaran daring pada awal masa pandemi, sehingga media pembelajaran yang digunakan didominasi oleh WhatsApp Group. Media WhatsApp tidak memungkinkan untuk melakukan tatap muka (live) dengan jumlah mahasiswa $>20$ orang, sehingga pembelajaran dilakukan dengan penugasan mandiri dan sangat minim adanya interaksi, diskusi, kolaborasi selama proses pembelajaran daring.

2. Penyampaian materi oleh dosen kurang efektif melalui pembelajaran daring. Pada pertanyaan ini, mahasiswa $55 \%$ menjawab Setuju, 27\% Sangat Setuju, 13\% Kurang Setuju, 5\% Tidak Setuju. Respon mahasiswa ini menjelaskan bahwa $82 \%$ mahasiswa memberikan respon negatif dan menggambarkan bahwa pembelajaran daring kurang efektif untuk memfasilitasi mahasiswa dalam menguasai materi perkuliahan. Hal ini dapat disebabkan karena media pembelajaran daring yang umumnya digunakan (WhatsApp) membatasi ruang interaksi antara dosen dan mahasiswa, sehingga dosen kesulitan untuk mengelaborasi materi pembelajaran secara langsung (interaksi dua arah).

3. Miskomunikasi antara dosen dan mahasiswa lebih sering terjadi pada pembelajaran daring. Pada pertanyaan ini, mahasiswa sebanyak $66 \%$ menjawab
Setuju, 11\% Setuju, 18\% Kurang Setuju, $5 \%$ Tidak Setuju. Respon mahasiswa ini menjelaskan bahwa $77 \%$ mahasiswa memberikan respon negatif dan menggambarkan bahwa pembelajaran daring kurang efektif memfasiltiasi interaksi antara dosen dan mahasiswa, sehingga seringkali terjadi miskomunikasi. Hal ini dapat disebabkan karena interaksi pembelajaran dari menggunakan WhatsApp hanya dapat dilakukan dengan tulisan, rekaman suara dan video.

4. Mengemukakan pendapat, pertanyaan, atau permasalahan lebih nyaman melalui pembelajaran daring. Pada pertanyaan ini, mahasiswa sebanyak $58 \%$ menjawab Kurang Setuju, 26\% Tidak Setuju, 16\% Setuju, 0\% Sangat Setuju. Respon mahasiswa ini menjelaskan bahwa $84 \%$ mahasiswa memberikan respon negatif dan menggambarkan bahwa mahasiswa merasa kesulitan untuk mengutarakan pendapat, pertanyaan, dan permasalahan kepada dosen pada pembelajaran daring. Hal ini dapat disebabkan karena pembelajaran daring kurang efektif memfasilitasi interaksi antara pembelajaran.

5. Diskusi dan kolaborasi antara dosen dan mahasiswa kurang efektif dalam pembelajaran daring. Pada pertanyaan ini, mahasiswa sebanyak $47 \%$ menjawab Setuju, 34\% Sangat Setuju, 16\% Kurang Setuju, 3\% Tidak Setuju. Respon mahasiswa ini menjelaskan bahwa $81 \%$ mahasiswa memberikan respon negatif dan menggambarkan bahwa pembelajaran daring kurang efektif dalam memfasilitasi interaksi dosen dan mahasiswa dalam berdiskusi dan berkolaborasi.

6. Penyelesaian masalah tentang materi perkuliahan lebih mudah dan cepat melalui pembelajaran daring. Pada pertanyaan ini, mahasiswa sebanyak $63 \%$ menjawab Kurang Setuju, 18\% Tidak Setuju, 19\% Setuju, 0\% Sangat Setuju. Respon mahasiswa ini menjelaskan bahwa $81 \%$ mahasiswa memberikan respon negatif dan menggambarkan bahwa pembelajaran kurang efektif dalam memfasilitasi interaksi dosen dan mahasiswa dalam menjelaskan, 
mengelaborasi, dan menyelesaikan berbagai hal tentang materi pembelajaran.

7. Respon/umpan balik kurang efektif pada pembelajaran daring. Pada pertanyaan ini, mahasiswa sebanyak $56 \%$ menjawab Setuju, 24\% Sangat Setuju, 18\% Kurang Setuju, 0\% Tidak Setuju. Respon mahasiswa ini menjelaskan bahwa $80 \%$ mahasiswa memberikan respon negatif dan menggambarkan bahwa pembelajaran daring kurang efektif dalam memfasilitasi interaksi dosen dan mahasiswa dalam proses diskusi dan umpan balik sangat terbatas.

8. Pembelajaran daring memudahkan saya berinteraksi dengan mahasiswa lainnya. Pada pertanyaan ini, mahasiswa sebanyak 52\% menjawab Kurang Setuju, 21\% Tidak Setuju, 24\% Setuju, 3\% Sangat Setuju. Respon mahasiswa ini menjelaskan bahwa $73 \%$ mahasiswa memberikan respon negatif dan menggambarkan bahwa pembelajaran daring kurang efektif dalam memfasilitasi interaksi antar mahasiswa.

9. Miskomunikasi antar mahasiswa lebih sering terjadi pada pembelajaran daring. Pada pertanyaan ini, mahasiswa sebanyak $58 \%$ menjawab Setuju, 13\% Sangat Setuju, 24\% Kurang Setuju, 5\% Tidak Setuju. Respon mahasiswa ini menjelaskan bahwa $71 \%$ mahasiswa memberikan respon negatif dan menggambarkan bahwa pembelajaran daring kurang efektif dalam memfasilitasi interaksi dan komunikasi antar mahasiswa, sehingga seringkali terjadi miskomunikasi.

10. Diskusi dan kolaborasi antar mahasiswa kurang efektif selama pembelajaran daring. Pada pertanyaan ini, mahasiswa sebanyak 58\% menjawab Setuju, 29\% Sangat Setuju, 13\% Kurang Setuju, 0\% Tidak Setuju. Respon mahasiswa ini menjelaskan bahwa $87 \%$ mahasiswa memberikan respon negatif dan menggambarkan bahwa pembelajaran daring kurang efektif dalam memfasilitasi ineraksi antar mahasiswa dalam berdiskusi dan berkolaborasi dalam proses pembelajaran.

11. Pelaksanaan evaluasi lebih objektif dalam pembelajaran daring. Pada pertanyaan ini, mahasiswa sebanyak $66 \%$ menjawab
Kurang Setuju, 10\% Tidak Setuju, 24\% Setuju, 0\% Sangat Setuju. Respon mahasiswa ini menjelaskan bahwa $76 \%$ mahasiswa memberikan respon negatif dan menggambarkan bahwa pembelajaran daring kurang efektif dalam memfasilitasi proses evaluasi pembelajaran yang objektif dan autentik, karena dosen kesulitan untuk menerapkan penilaian proses (performance assesment).

12. Lingkungan belajar mendukung pembelajaran daring. Pada pertanyaan ini, mahasiswa sebanyak $50 \%$ menjawab Setuju, 5\% Sangat Setuju, 34\% Kurang Setuju, $11 \%$ Tidak Setuju. Respon mahasiswa ini menjelaskan bahwa 55\% mahasiswa memberikan respon positif dan menggambarkan bahwa lingkungan sekitar memberikan dukungan yang baik maksimal kepada mahasiswa dalam mengikuti pembelajaran daring. Kendati demikian, cukup banyak mahasiswa (45\%) memberikan respon negatif atau tidak mendapatkan dukungan yang baik dari lingkungan sekitar dalam mengikuti pembelajaran daring.

13. Pembelajaran daring meningkatkan aktivitas belajar saya. Pada pertanyaan ini, mahasiswa sebanyak $48 \%$ menjawab Kurang Setuju, 5\% Tidak Setuju, 42\% Setuju, 5\% Sangat Setuju. Respon mahasiswa ini menjelaskan bahwa 55\% memberikan respon negatif dan menggambarkan bahwa pembelajaran daring belum termotivasi untuk meningkatkan frekuensi belajarnya, namun 49\% lainnya memberikan respon positif (sebaliknya) yang artinya bahwa sebagian mahasiswa telah meningkatkan frekuensi belajarnya selama ikut pembelajaran daring.

14. Pembelajaran daring meningkatkan kemandirian saya dalam belajar. Pada pertanyaan ini, mahasiswa sebanyak $55 \%$ menjawab Setuju, 8\% Sangat Setuju, 37\% Kurang Setuju, 0\% Tidak Setuju. Respon mahasiswa ini menjelaskan bahwa 63\% mahasiswa memberikan respon positif dan menggambarkan bahwa pembelajaran daring telah memotivasi mahasiswa untuk lebih mandiri dalam belajar. 
Data persepsi mahasiswa pendidikan biologi terhadap pembelajaran daring pada masa pandemi covid-19 dianalisis deskriptif dengan hasil sebagaimana disajikan pada Tabel 3 berikut ini.

Tabel 3. Deskripsi data persepsi mahasiswa

\begin{tabular}{lcccc}
\hline \multicolumn{1}{c}{ Varians } & $\begin{array}{c}\Sigma \\
\text { Mhs }\end{array}$ & $\begin{array}{c}\Sigma \\
\text { Skor }\end{array}$ & $\begin{array}{c}\text { Rata- } \\
\text { Rata }\end{array}$ & Kriteria \\
\hline Persepsi & 38 & 86,64 & 2,28 & $\begin{array}{c}\text { Cukup } \\
\text { Baik }\end{array}$ \\
\hline
\end{tabular}

Berdasalkan data hasil analasis pada tabel 2 di atas menunjukkan bahwa persepsi mahasiswa pendidikan biologi terhadap pembelajaran daring di masa pandemi covid-19 yaitu memiliki rata-rata sebesar 2,28 dengan kategori Cukup Baik. Hasil penelitian ini menjelaskan bahwa pembelajaran daring di Program Studi Pendidikan Biologi pada Semester Genap Tahun Akademik 2019/2020 atau awal pandemi covid-19 berlangsung kurang efektif.

Elaborasi hasil penelitian ini menunjukkan bahwa pembelajaran daring pada pendidikan biologi di Semester Genap Tahun Akademik 2019/2020 atau awal pandemi covid-19 adalah kurang efektif. Hal ini dapat disebabkan karena banyak faktor, salah satunya adalah faktor persiapan yang belum maksimal, mengingat pada awal penerapan pembelajaran daring di awal masa pandemi yang sangat mendadak yaitu setelah jadwal perkuliahan tatap muka (luring) dimulai. Persiapan yang tidak maksimal mempengaruhi efektivitas pembelajaran daring yang diselenggarakan, sedangkan dosen, mahasiswa, media, sumber belajar, peralatan pendukung, dan lingkungan belajar disediakan secara mendadak. Hal ini sesuai dengan pendapat Oktavian \& Aldya (2020); Ulfah \& Suryantoro (2020); Daheri, et al (2020) bahwa sesungguhnya pembelajaran daring membutuhkan effort dan dukungan yang maksimal dari semua pihak baik itu pendidik dan keluarga. Pendidik dan orang tua dituntut menciptakan lingkungan belajar yang integratif dan memenuhi berbagai komponen esensial pembelajaran yakni diskursif, adaptif, interaktif dan reflektif.

Persiapan yang sangat terbatas 'memaksa' dosen menggunakan media pembelajaran daring yang familiar dan dimiliki oleh semua mahasiswa seperti WhatsApp. Penggunaan WhatsApp, membuat pembelajaran daring kurang efektif karena keterbatasan interaksi dua arah antara dosen dengan mahasiswa ataupun antar mahasiswa secara dua arah, sehingga dosen hanya dapat memfasilitasi pembelajaran dalam bentuk tulisan, rekaman suara, video, dan tugas mandiri. Hal ini sesuai dengan pendapat Batubara \& Batubara (2020) bahwa penjelasan detil dari pendidik melalui pesan grup apalagi video cukup jarang didapat. Padahal video penjelasan atau tutorial dapat memberikan pemahaman lebih baik dibandingkan hanya diberikan tuga mandiri. Hasi penelitian Daheri, et al (2020) bahwa $85 \%$ responden mengharapkan pendidik memberikan penjelasan yang memadai untuk tugas yang diberikan. Beberapa menyarankan melalui video call dan yang lainnya penjelasan melalui share video. Media WhatsApp tidak memungkinkan untuk video call dengan semua peserta didik dalam waktu bersamaan, sehingga interaksi dua arah sangat terbatas dalam pembelajaran daring antara dosen dan mahasiswa ataupun antar mahasiswa.

Respon mahasiswa menjelaskan bahwa pembelajaran daring memiliki keterbatasan dalam proses interaksi, diskusi, kolaborasi, umpan balik, dan respon. Kondisi ini membuat mahasiswa mengalami keterbatasan dalam menyampaikan pendapatan, pertanyaan, dan masalah yang dihadapi dalam pembelajaran daring, sehingga memungkinkan untuk terjadi miskomunikasi antara dosen dan mahasiswa ataupun antar mahasiswa. Hal ini sesuai dengan pendapat Sadikin \& Hamidah (2020) bahwa pembelajaran daring memiliki tantangan khusus, lokasi mahasiswa dan dosen yang terpisah saat melaksanakan menyebabkan dosen tidak dapat berinteraksi, membimbing, dan mengawasi secara langsung kegiatan mahasiswa selama proses pembelajaran. Akibatnya, tidak ada jaminan bahwa mahasiswa sunguh-sungguh dalam mendengarkan elaborasi materi dari dosen, sehingga dimungkinkan adanya miskomunikasi. Mahasiswa lebih sering menghayal pada perkuliahan daring 
dibandingkan ketika kuliah tatap muka (Szpunar, Moulton, \& Schacter, 2013).

Pembelajaran daring diakui mahasiswa kurang efektif untuk mendapatkan penjelasan dan penyelesaian masalah materi perkuliahan dari dosen. Hal ini dikarenakan sesuai dengan hasil penelitian Sadikin \& Hamidah (2020) bahwa tidak sedikit mahasiwa yang kesulitan dalam memahami materi perkuliahan yang diberikan secara daring. Bahan ajar/tugas mandiri yang biasa disampaikan dalam bentuk bacaan yang tidak mudah dipahami secara menyeluruh oleh mahasiswa. Mahasiswa berasumsi bahwa materi dan tugas mandiri tidak cukup karena perlu penjelasan secara langsung oleh dosen (Sadikin \& Hakim, 2019; Swan, 2002).

Pembelajaran daring yang masih dirasa kurang efektif, memiliki dampak positif bagi mahasiswa dalam membentuk kemandiriannya. Mahasiswa mengaku bahwa selama proses pembelajaran daring membuatnya lebih giat belajar dan madiri dalam menyelesaikan tugas perkuliahan. Hal ini sesuai dengan hasil penelitian Sadikin \& Hamidah (2020) bahwa pembelajaran daring juga memiliki kelebihan mampu menumbuhkan kemandirian belajar (self regulated learning). Penggunaan aplikasi online mampu meningkatkan kemandirian belajar (Oknisih \& Suyoto, 2019). Kuo et al., (2014) dalam Sadikin \& Hamidah (2020) menyatakan bahwa pembelajaran daring lebih bersifat berpusat pada peserta didik yang menyebabkan mereka mampu memunculkan tanggung jawab dan otonomi dalam belajar (learning autuonomy). Belajar secara daring menuntut mahasiswa mempersiapkan sendiri pembelajarannya, mengevaluasi, mengatur dan secara simultan mempertahankan motiviasi dalam belajar (Aina, M., 2016). Lebih lanjut Sobron \& Bayu, (2019) menyatakan bahwa pembelajaran daring dapat meningkatkan minat peserta didik.

\section{KESIMPULAN}

Berdasarkan hasil penelitian dan pembahasan di atas, maka dapat disimpulkan bahwa pembelajaran daring di Program Studi Pendidikan Biologi pada Semester Genap
Tahun Akademik 2019/2020 atau awal pandemi covid-19 berlangsung kurang efektif. Hal ini dibuktikan dengan deksripsi data penelitian bahwa (1) persepsi mahasiswa pendidikan biologi adalah $>70 \%$ memberikan respon negatif pada setiap jawaban tentang efektivitas pembelajaran daring, (2) analisis deskriptif data persepsi mahasiswa pendidikan biologi terhadap pembelajaran daring menghasilkan rata-rata sebesar 2,28 atau kategori Cukup Baik.

\section{DAFTAR PUSTAKA}

Adijaya, N. \& Santosa, L.P. 2018. Persepsi Mahasiswa dalam Pembelajaran Online. Jurnal Wanastra, 10 (2), 105-110. https://doi.org/10.31294/w.v10i2.3931

Aina, M. 2016. Pengembangan Multimedia Interaktif menggunakan camtasia studio 8 pada Pembelajaran Biologi materi Kultur Jaringan untuk Siswa SMA kelas XI MIA. Jurnal Biodik, 2 (1).

Batubara, H. H., \& Batubara, D. S. (2020). Penggunaan Video Tutorial untuk Mendukung Pembelajaran Daring di Masa Pandemi Virus Corona. Muallimuna: Jurnal Madrasah Ibtidaiyah, $\quad 5(2), \quad$ 74-84. http://dx.doi.org/10.31602/muallimuna.v $\underline{5 \mathrm{i} 2.2950}$

Daheri, M., Juliana, Deriwanto \& Amda, A.D. 2020. Efektivitas WhatsApp sebagai Media Belajar Daring. Jurnal Basicedu, $4 \quad$ (4), 775-783. https://doi.org/10.31004/basicedu.v4i4.4 $\underline{45}$

Firman, F., \& Rahayu, S. 2020. Pembelajaran Online di Tengah Pandemi Covid-19. Indonesian Journal of Educational Science (IJES), 2 (2), 81-89. https://doi.org/10.31605/ijes.v2i2.659

Fink, A. (2011). How to sample in surveys. In how to sample in surveys (2nd edition). Thousand Oaks, CA: SAGE Publication.

Gultom, C.R. \& Sitanggang, S.G.M. 2020. Persepsi Mahasiswa Unika terhadap Kuliah Online di Masa Pandemi Covid 19. Jurnal Pendidikan Bahasa Indonesia dan Sastra (PEDISTRA), 3 (1), 6-15. http://dx.doi.org/10.1234/pbis.v3i1.771 
Kemendikbud, 2020. Pusat Pendidikan dan Pelatihan Pegawai Kementrian Pendidikan dan Kebudayaan. https://pusdiklat.kemdikbud.go.id/suratedaran-mendikbud-no-4tahun-2020tentang-pelaksanaan-kebijakanpendidikan-dalammasadaruratpenyebaran-corona-virusdisease-covid-1-9/, (Online) diakses 07 Oktober 2020

Kuntarto, E. 2017. Keefektifan Model Pembelajaran Daring dalam PerkuliahanBahasa Indonesia di Perguruan Tinggi. Indonesian Language Education and Literature, 3(1), 99-110. http://dx.doi.org/10.24235/ileal.v3i1.182 $\underline{0}$

Maulah, S., Nurul, F. \& Ummah, N.R. 2020. Persepsi Mahasiswa Biologi terhadap Perkuliahan Daring sebagai Sarana Pembelajaran Selama Pandemi Covid19. ALVEOLI: Jurnal Pendidikan Biologi, 1 (2), 49-61. https://alveoli.iainjember.ac.id/index.php/alv/article/view/6

Muliadi, A. 2020. Sikap Entrepreneur Mahasiswa Pendidikan Biologi. Jurnal Ilmu Sosial dan Pendidikan, 4 (3), 286291.

http://dx.doi.org/10.36312/jisip.v4i3.120 $\underline{8}$

Muliadi, A. 2020. Perbedaan Gender dalam Sikap Entrepreneur Mahasiswa Pendidikan Biologi. Jurnal Ilmiah Mandala Education, 6 (2), 329-334. http://dx.doi.org/10.36312/jime.v6i2.143 $\underline{9}$

Muliadi, A. 2020. Microbiology Learning Based On Bioentrepreneurship: Prospective Teacher's Perception. Jurnal Ilmu Sosial dan Pendidikan, 4 (4), 352357.

http://dx.doi.org/10.36312/jisip.v4i4.152 $\underline{7}$

Muliadi, A. \& Mirawati, B. 2020. The Impact of Personal Attitude and Subjective Norm on Entrepreneurial Interest of Biological Education Students. ESaintika: Jurnal Penelitian dan Pengkajian Ilmu Pendidikan, 4 (3). https://doi.org/10.36312/esaintika.v4i3.307

Muliadi, A., Asri, I.H. \& Lestarini, Y. 2020. Efek Pengetahuan dan Lingkungan Keluarga terhadap Sikap Entrepreneur Mahasiswa. Educatio: Jurnal Ilmu Kependidikan, 15 https://doi.org/10.29408/edc.v15i2.2836

Muliadi, A. 2019. Pembelajaran Biologi Berbasis Entrpreneurship. Proceeding National Conference: Education, Social Science, and Humaniora, 1 (1), 269-275.

Oktavian, R., \& Aldya, R. F. 2020. Efektivitas Pembelajaran Daring Terintegrasi di Era Pendidikan 4.0. Didaktis: Jurnal Pendidikan dan Ilmu Pengetahuan, 20(2), 129-135. http://dx.doi.org/10.30651/didaktis.v20i2 .4763

Oknisih, N., \& Suyoto, S. 2019. Penggunaan APLEN (aplikasi online) sebagai Upaya Kemandirian Belajar Siswa. Seminar NasionalPendidikan Dasar, 1 (1), $477-$ 483.

http://eproceedings.umpwr.ac.id/index.p $\mathrm{hp} / \mathrm{semnaspgsd} /$ article/view/1056/905

Pangondian, R. A., Santosa, P. I., \& Nugroho, E. 2019. Faktor-Faktor Yang Mempengaruhi Kesuksesan Pembelajaran Daring Dalam Revolusi Industri 4.0. Seminar Nasional Teknologi Komputer \& Sains (SAINTEKS), 1 (1), 56-60. https://www.prosiding.seminarid.com/index.php/sainteks/article/view/1 22

Sadikin, A. \& Hamidah, A. 2020. Pembelajaran Daring di Tengah Wabah Covid-19. BIODIK: Jurnal Ilmiah Pendidikan Biologi, 6 (2), 214-224. https://doi.org/10.22437/bio.v6i2.9759

Saifuddin, M.F. 2017. E-Learning dalam Persepsi Mahasiswa. Jurnal Varia Pendidikan, 29 (2), 102-109.

Singarimbun, M. \& Efendi, S. 2006. Metode Penelitian Survai (Edisi Revisi). Jakarta Barat: Pustaka LP3ES Indonesia.

Sobron, A. N., \& Bayu, R. 2019. Persepsi Siswa dalam Studi Pengaruh Daring Learning Terhadap Minat Belajar IPA. 
SCAFFOLDING: Jurnal Pendidikan Islam dan Multikulturalisme, 1 (2), 3038.

https://doi.org/10.37680/scaffolding.v1i2 .117

Sugiyono. 2017. Metode Penelitian Kualitatif, Kuantitatif, dan $R \& D$. Bandung: Alfabeta.

Szpunar, K. K., Moulton, S. T., \& Schacter, D. L. 2013. Mind wandering and education: From the classroom to online learning. Frontiers in Psychology, 4 (Article 495) 1-7. https://dx.doi.org/10.3389\%2Ffpsyg.201 3.00495

Swan, K. 2002. Building Learning Communities in Online Courses: the importance of interaction. Education, Communication \& Information, 2 (1), 23-49.

https://doi.org/10.1080/14636310220000 $\underline{05016}$

Ulfah, Y., \& Suryantoro, A. (2020). Studi Awal Tentang Penggunaan Media Daring Selama Pandemi Corona Di SMPN Purworejo Lampung Tengah. Al Jahiz: Journal of Biology Education Research, 1 (1), 34-43. https://ejournal.metrouniv.ac.id/index.php/AlJahiz/article/view/2046

Yuniarti, R.D. 2010. Potensi E-Learning melalui Sistem Kuliah On-Line dalam Meningkatkan Kualitas Pembelajaran di Prodi Tata Niaga Jurusan Pendidikan Ekonomi FPEB-UPI. Jurnal ANAJERIAL, 8 (16), 66-77. https://doi.org/10.17509/manajerial.v9i1. 1215

Zhafira, N.H., Ertika, Y. \& Chairiyaton. 2020. Persepsi Mahasiswa terhadap Perkuliahan Daring sebagai Sarana Pembelajaran Selama Masa Karantina Covid-19. Jurnal Bisnis dan Kajian Strategi Manajemen, 4 (1), 37-45. https://doi.org/10.35308/jbkan.v4i1.1981 